Correspondence

Su Sheng Yang

yangssh@cau.edu.cn

\section{Jeotgalicoccus halophilus sp. nov., isolated from salt lakes}

\author{
Wen-Yan Liu, ${ }^{1,2}$ Lin-Lin Jiang, ${ }^{3}$ Chun-Jing Guo ${ }^{3}$ and Su Sheng Yang ${ }^{1}$
}

${ }^{1}$ Department of Microbiology and Immunology, College of Biological Sciences, China Agricultural University, Key Laboratory for Agro-Microbial Resource and Application, Ministry of Agriculture, Beijing 100193, PR China

${ }^{2}$ National Engineering Lab. of Biohydrometallurgy, General Research Institute for Nonferrous Metals, Beijing 100088, PR China

${ }^{3}$ Northeast Agricultural University, Haerbin 150030, PR China

Two slightly halophilic bacterial strains, $\mathrm{C} 1-52^{\top}$ and $\mathrm{YD}-9$, were isolated from Daban and Aiding salt lakes in Xinjiang, China, respectively. The isolates were Gram-positive, non-endosporeforming, non-motile, facultatively anaerobic cocci. Colonies were pale yellow, and a light pink, diffusible pigment was produced after a few additional days of incubation. The isolates grew optimally with $2-3 \%(\mathrm{w} / \mathrm{v}) \mathrm{NaCl}$, at $\mathrm{pH} 7.5$ and at $30-35{ }^{\circ} \mathrm{C}$. The peptidoglycan type was L-LysGly $_{3-4}-\mathrm{L}-\mathrm{Ala}$ (Gly). The menaquinones were MK-7 (83.2\%) and MK-6 (16.8\%). The major fatty acids $(>10 \%)$ were anteiso- $C_{15: 0}$ and iso- $C_{15: 0}$. The DNA G $+C$ content of strains $C 1-52^{\top}$ and YD-9 was 41.2 and 41.0 mol\%, respectively. Phylogenetic analysis based on 16S rRNA gene sequences revealed that strains $\mathrm{C} 1-52^{\top}$ and $\mathrm{YD}-9$ were closely related to Jeotgalicoccus psychrophilus YKJ-115 ${ }^{\top}$ (98.0 and $97.1 \%$ 16S rRNA gene sequence similarity, respectively), followed by Jeotgalicoccus halotolerans YKJ-101 ${ }^{\top}$ (97.1 and 96.8\%). Strains $\mathrm{C} 1-52^{\top}$ and YD-9 shared, respectively, 20 and $11 \%$ DNA-DNA relatedness with J. halotolerans JCM $11198^{\top}$ and 8 and $13 \%$ with $J$. psychrophilus JCM $11199^{\top}$. DNA-DNA relatedness between the isolates was $91 \%$. On the basis of phenotypic and phylogenetic distinctiveness, strains $\mathrm{C} 1-52^{\top}$ and YD-9 belonged to the same species, which should be placed in the genus Jeotgalicoccus as a novel species. The name Jeotgalicoccus halophilus sp. nov. is proposed, with the type strain $\mathrm{C} 1-52^{\top}$ $\left(=\right.$ CGMCC $1.8911^{\top}=$ NBRC $\left.105788^{\top}\right)$.
The genus Jeotgalicoccus was originally proposed by Yoon et al. (2003) with two species, Jeotgalicoccus halotolerans and Jeotgalicoccus psychrophilus, which were isolated from a traditional Korean food, jeotgal. A third species, Jeotgalicoccus pinnipedialis, from the oral cavity of a southern elephant seal, was subsequently described by Hoyles et al. (2004). To date, two more species have been described within this genus: Jeotgalicoccus marinus (Chen et al., 2009), from a sea urchin collected from the South China Sea, and Jeotgalicoccus huakuii (Guo et al., 2010), from a seaside soil sample in Shandong province of China. The main characteristics of this genus are Gram-positive, non-motile, non-endospore-forming, catalase- and oxidase-positive cocci. The predominant isoprenoid quinone is $\mathrm{MK}-7$, the major fatty acids are anteiso- $\mathrm{C}_{15: 0}$ and iso- $\mathrm{C}_{15: 0}$, the DNA

The GenBank/EMBL/DDBJ accession numbers for the $16 \mathrm{~S}$ rRNA gene sequences of strains $\mathrm{C} 1-52^{\top}$ and YD-9 are FJ386517 and GQ304892, respectively.

A supplementary figure and table are available with the online version of this paper.
$\mathrm{G}+\mathrm{C}$ content is $36.8-42 \mathrm{~mol} \%$ and the cell-wall peptidoglycan is L-Lys-Gly ${ }_{3-4}-\mathrm{L}-\mathrm{Ala}(\mathrm{Gly})$ (Yoon et al., 2003).

In the course of investigating the microbial diversity of salt lakes in Xinjiang, we isolated two Jeotgalicoccus-like organisms, C1-52 $2^{\mathrm{T}}$ and YD-9, from the sediments of

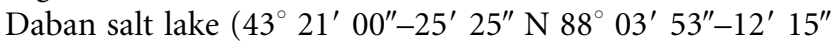
E) and Aiding salt lake $\left(42^{\circ} 32^{\prime} 10^{\prime \prime}-49^{\prime} 13^{\prime \prime} \mathrm{N} 89^{\circ} 10^{\prime} 32^{\prime \prime}-\right.$ $\left.54^{\prime} 32^{\prime \prime} \mathrm{E}\right)$, respectively. At the time of sampling, the $\mathrm{NaCl}$ concentration and $\mathrm{pH}$ of sediments collected from Daban salt lake were $14.7-16.9 \%$ and $\mathrm{pH} 7.6-7.8$ and those of sediments from Aiding salt lake were 12.1-15.4\% and $\mathrm{pH}$ 7.1-7.3. For isolation, the samples were suspended in sterilized water with $2 \%(\mathrm{w} / \mathrm{v}) \mathrm{NaCl}$, serially diluted and spread on improved Gibbson medium (containing $\mathrm{l}^{-1}: 5 \mathrm{~g}$ tryptone, $10 \mathrm{~g}$ yeast extract, $5 \mathrm{~g}$ casein, $2 \mathrm{~g} \mathrm{KCl}, 20 \mathrm{~g}$ $\mathrm{MgSO}_{4} \cdot 7 \mathrm{H}_{2} \mathrm{O}, 20 \mathrm{~g} \mathrm{NaCl}, 3 \mathrm{~g}$ trisodium citrate; $\mathrm{pH} 7.4$; $\mathrm{Xu}$ et al., 1995). The isolation medium was also used for maintenance of the cultures.

Cell morphology was examined by phase-contrast microscopy (Eclipse 50i; Nikon) and transmission electron 
microscopy (JEM 1230; JEOL) after $16 \mathrm{~h}$. Motility was examined by phase-contrast microscopy. Colony morphology was examined after 3 days at $33{ }^{\circ} \mathrm{C}(\mathrm{pH}$ 7.5). Gram reaction was determined according to the methods described by Gregersen (1978) and Doetsch (1981). Cells were Gram-positive, non-motile cocci $(0.5-0.8 \mu \mathrm{m}$; Supplementary Fig. S1, available in IJSEM Online). Colonies were circular, smooth, entire, slightly raised, pale yellow and 1-2 $\mathrm{mm}$ in diameter after 3 days. The two isolates and the reference strains J. halotolerans JCM $11198^{\mathrm{T}}$ and $J$. psychrophilus JCM $11199^{\mathrm{T}}$ produced a light pink, diffusible pigment after a few additional days of incubation.

Physiological and biochemical tests were performed according to the recently published notes on the characterization of prokaryotic strains for taxonomic purposes (Tindall et al., 2010). Unless otherwise indicated, all tests were performed in test tubes in triplicate at $33{ }^{\circ} \mathrm{C}$ using maintenance medium containing $5 \%(\mathrm{w} / \mathrm{v}) \mathrm{NaCl}$ and uninoculated tubes were used as negative controls. Growth at 4 and $5-55{ }^{\circ} \mathrm{C}$ (in increments of $5{ }^{\circ} \mathrm{C}$ ) at $\mathrm{pH} 7.5$ and at $\mathrm{pH} 5.0-11.0$ (in increments of $0.5 \mathrm{pH}$ units) at $33^{\circ} \mathrm{C}$ was estimated in liquid medium by monitoring the increase in optical density at $600 \mathrm{~nm}$. For the $\mathrm{pH}$ experiments, the buffers described by Chen et al. (2007) were used. Growth with $0-0.5 \% \mathrm{NaCl}$ (in increments of $0.1 \%$ ) and $1-25 \%$ $(\mathrm{w} / \mathrm{v}) \mathrm{NaCl}$ (in increments of $1 \%$ ) at $33{ }^{\circ} \mathrm{C}$ and $\mathrm{pH} 7.5$ was estimated in liquid MM63 medium (Larsen et al., 1987), which is a minimal medium with sucrose as the carbon source. Growth under anaerobic conditions was determined after incubation in a $\mathrm{CO}_{2}$ incubator on anaerobically prepared medium. Catalase activity was detected by adding $3 \% \mathrm{H}_{2} \mathrm{O}_{2}$ to culture plates. The oxidase reaction was performed on filter paper moistened with $1 \%(\mathrm{w} / \mathrm{v})$ aqueous solution of tetramethyl-p-phenylenediamine. Urease, arginine dihydrolase, phosphatase and lecithinase activities and hydrolysis of casein, aesculin, hypoxanthine, tyrosine, xanthine, starch, Tween 80 and gelatin were determined as described by Cowan \& Steel (1965) and Lányí (1987). The methyl red and Voges-Proskauer tests and tests for indole and $\mathrm{H}_{2} \mathrm{~S}$ production, nitrate reduction, phenylalanine deaminase and lysine and ornithine decarboxylases were performed as recommended by Smibert \& Krieg (1994) and Dong \& Cai (2001). Antibiotic susceptibility was determined on plates containing the following $\left(\mu \mathrm{g} \mathrm{ml}^{-1}\right)$ : rifampicin (5), streptomycin (100), ampicillin (30), gentamicin (40), chloramphenicol (20), kanamycin (100), erythromycin (50), tetracycline (20), spectinomycin (50) and nalidixic acid (30). Tests for utilization of various substrates as sole carbon and energy sources were performed according to the methods described by Shirling \& Gottlieb (1966) and acid production from carbohydrates was determined as described by Leifson (1963), using substrate concentrations of $0.5 \%(w / v)$. The biochemical tests were also performed with the reference strains J. halotolerans JCM $11198^{\mathrm{T}}$ and J. psychrophilus JCM $11199^{\mathrm{T}}$ (Table 1). The biochemical properties of the reference strains determined in this study were the same as those reported previously. The detailed physiological and biochemical characteristics of strains $\mathrm{C} 1-52^{\mathrm{T}}$ and YD-9 are given in the species description and the phenotypic differences between the isolates and the type strains of species of the genus Jeotgalicoccus are given in Table 1.

For analysis of the cell-wall peptidoglycan type and menaquinones, biomass of strain $\mathrm{C} 1-52^{\mathrm{T}}$ was harvested after incubation on maintenance medium supplemented with $2 \%(\mathrm{w} / \mathrm{v}) \mathrm{NaCl}(\mathrm{pH} 7.5)$ at $33{ }^{\circ} \mathrm{C}$ for $18 \mathrm{~h}$. Cell walls were prepared using the methods described by Schleifer \& Kandler (1972) and the determination of the major amino acid was carried out by using Amino-acid Analysers (A300, membraPure). Menaquinones were analysed as described by Collins (1985) using reversed-phase HPLC (HP 1050; Hewlett Packard), using Arthrobacter nicotinovorans CGMCC $1.1933^{\mathrm{T}}$ and J. halotolerans JCM $11198^{\mathrm{T}}$ as the reference strains. Fatty acids of the isolates and the reference strains were analysed according to the Microbial Identification System (MIDI) using cells grown in maintenance medium supplemented with $2 \%(\mathrm{w} / \mathrm{v}) \mathrm{NaCl}(\mathrm{pH} 7.5)$ in Erlenmeyer flasks on a rotary shaker (150 r.p.m.) at $33{ }^{\circ} \mathrm{C}$ $\left(25{ }^{\circ} \mathrm{C}\right.$ for J. psychrophilus JCM $\left.11199^{\mathrm{T}}\right)$ for 1 day. The major amino acids of the cell-wall hydrolysates were glycine, lysine and alanine, which corresponds to the A3 $\alpha$ peptidoglycan type, based on L-Lys-Gly ${ }_{3-4}-\mathrm{L}-\mathrm{Ala}(\mathrm{Gly})$, described for the genus Jeotgalicoccus. The quinones of strain $\mathrm{C} 1-52^{\mathrm{T}}$ were MK-7 (83.2\%) and MK-6 (16.8\%). The major cellular fatty acids in strains $\mathrm{C} 1-52^{\mathrm{T}}$ and YD-9 were, respectively, anteiso- $\mathrm{C}_{15: 0}(52.3$ and $54.2 \%)$, iso- $\mathrm{C}_{15: 0}(26.1$ and $22.1 \%)$ and iso- $\mathrm{C}_{17: 1} \omega 10 c(7.3$ and $5.9 \%)$. The major cellular fatty acid compositions obtained for the two reference strains were similar to the original descriptions. Detailed information on the cellular fatty acid compositions of strains C1-52 and YD-9 is provided in Supplementary Table S1.

Chromosomal DNA was extracted and purified according to standard methods (Marmur, 1961). The determination of DNA G $+\mathrm{C}$ content was carried out by the thermal denaturation method using a BIO-20 UV spectrophotometer according to Marmur \& Doty (1962), with Escherichia coli $\mathrm{K}-12$ as the standard. The DNA G+C content of strains $\mathrm{C} 1-52^{\mathrm{T}}$ and YD-9 was 41.2 and $41.0 \mathrm{~mol} \%$, respectively. These values are within the range for the genus Jeotgalicoccus (Yoon et al., 2003).

The 16S rRNA gene sequences of strains $\mathrm{C} 1-52^{\mathrm{T}}$ and YD-9 were amplified as described by Duckworth et al. (1996) and the amplification products were sequenced with an automated DNA sequencer (373A; Applied Biosystems). The almost complete 16S rRNA gene sequences of strains C1-52 ${ }^{\mathrm{T}}$ (1457 bp) and YD-9 (1457 bp) were compared with sequences in public databases using BLAST via the National Center for Biotechnology Information. Pairwise sequence similarities were calculated using BioEdit (Hall, 1999). A multiple sequence alignment was created using CLUSTAL X (Thompson et al., 1997). The continuous stretches of nucleotides in the alignment, without any 
Table 1. Differential characteristics of strains $C 1-52^{\top}$ and YD-9 and members of the genus Jeotgalicoccus

Strains: 1, Jeotgalicoccus halophilus sp. nov. C1-52 ${ }^{\mathrm{T}}$ and YD-9 (data from this study); 2, J. halotolerans JCM 11198 ${ }^{\mathrm{T}} ; 3$, J. psychrophilus JCM 11199 ${ }^{\mathrm{T}}$ (data in columns 2 and 3 from Yoon et al., 2003 unless otherwise stated); 4, J. pinnipedialis CIP 107946 ${ }^{\mathrm{T}}$ (Hoyles et al., 2004); 5, J. huakuii JCM $15687^{\mathrm{T}}$ (Guo et al., 2010); 6, J. marinus DSM $19772^{\mathrm{T}}$ (Chen et al., 2009). +, Positive; w, weakly positive; -, negative.

\begin{tabular}{|c|c|c|c|c|c|c|}
\hline Characteristic & 1 & 2 & 3 & 4 & 5 & 6 \\
\hline Pigment & Light pink & Light pink ${ }^{\star}$ & Light pink ${ }^{*}$ & Buff or fawn & White & Creamy white \\
\hline \multicolumn{7}{|l|}{$\mathrm{NaCl}$ for growth $(\mathrm{w} / \mathrm{v}, \%)$} \\
\hline Range & $0.1-16$ & $0-20$ & $>0-14$ & $>0,<14$ & $0-23$ & $0.5-25$ \\
\hline Optimum & $2-3$ & $2-5$ & $2-5$ & $2-5$ & $3-8$ & $5-10$ \\
\hline \multicolumn{7}{|l|}{ Temperature for growth $\left({ }^{\circ} \mathrm{C}\right)$} \\
\hline Range & $4-40$ & $4-42$ & $4-34$ & $>4-42$ & $4-43$ & $10-45$ \\
\hline Optimum & $30-35$ & $30-35$ & $20-25$ & $28-35$ & $28-37$ & $25-30$ \\
\hline \multicolumn{7}{|l|}{$\mathrm{pH}$ for growth } \\
\hline Range & $5.5-10$ & $>5.5$ & $>5.5$ & $>5$ & $>4.5$ & $6-10$ \\
\hline Optimum & 7.5 & $7-8$ & $7-8$ & $7-8$ & $6.5-10$ & $7-8$ \\
\hline Urease & + & $-{ }^{*}$ & $-*$ & - & - & - \\
\hline \multicolumn{7}{|l|}{ Hydrolysis of: } \\
\hline Casein & + & $-{ }^{*}$ & $-*$ & + & - & - \\
\hline Starch & + & $-{ }^{*}$ & $-{ }^{*}$ & - & - & - \\
\hline Tyrosine & + & $+^{*}$ & $+^{*}$ & - & + & - \\
\hline Xanthine & - & $-*$ & $-*$ & + & - & - \\
\hline \multicolumn{7}{|l|}{ Acid production from: } \\
\hline Arabinose & - & $+^{*}$ & $-{ }^{*}$ & - & + & + \\
\hline Fructose & + & - & $-*$ & - & + & + \\
\hline D-Glucose & + & - & $-*$ & $\mathrm{w}$ & - & + \\
\hline D-Mannitol & $+\dagger /-$ & $+^{*}$ & $-*$ & - & - & + \\
\hline Sucrose & + & - & $\mathrm{w}$ & w & - & - \\
\hline DNA G $+\mathrm{C}$ content $(\mathrm{mol} \%)$ & $41.2 \dagger / 41.0$ & 42 & 42 & 38.6 & 36.8 & 40.3 \\
\hline
\end{tabular}

${ }^{\star}$ Data from this study and are the same as those reported previously.

$\dagger$ Data for strain $\mathrm{C} 1-52^{\mathrm{T}}$.

ambiguous bases or gaps, were used to reconstruct phylogenetic trees using MEGA version 3.1 (Kumar et al. 2004). Distances were calculated according to Kimura's two-parameter model (Kimura, 1980) and clustering was performed using the neighbour-joining, maximum-parsimony and minimum-evolution methods. The stability of the relationships was assessed using bootstrap analysis with 1000 replications. Because of the highly similar tree topologies obtained with the different clustering methods, only the neighbour-joining phylogenetic tree is shown (Fig. 1). 16S rRNA gene sequence comparisons revealed that strains $\mathrm{C} 1-52^{\mathrm{T}}$ and $\mathrm{YD}-9$ were most similar to $\mathrm{J}$. psychrophilus YKJ-115 ${ }^{\mathrm{T}}$ (98.0 and 97.1\% 16S rRNA gene sequence similarity, respectively), J. halotolerans $\mathrm{YKJ}-101^{\mathrm{T}}$ (97.1 and 96.8\%), J. huakuii NY-2 ${ }^{\mathrm{T}}$ (94.8 and 95.2\%), J. marinus JSM $076033^{\mathrm{T}}$ (94.6 and $\left.95.7 \%\right)$, J. pinnipedialis CCUG $42722^{\mathrm{T}}$ (92.2 and 91.7\%), Salinicoccus siamensis PN1-2 ${ }^{\mathrm{T}}$ (91.8 and 91.7\%), Salinicoccus roseus DSM $5351^{\mathrm{T}}$ (91.7 and $91.5 \%$ ) and Salinicoccus alkaliphilus $\mathrm{T}^{\mathrm{T}}$ (91.6 and $91.4 \%$ ). 16S rRNA gene sequence similarity between the isolates was $99.1 \%$. The phylogenetic analysis indicated that strains $C 1-52^{\mathrm{T}}$ and YD-9 and the type strains of the five recognized species of the genus Jeotgalicoccus were most closely related and formed a distinct clade in the phylogenetic tree with significant bootstrap support (99\%), within which the isolates formed a distinct subcluster (Fig. 1).

The phenotypic and chemotaxonomic characteristics of the isolates were also consistent with the genus Jeogalicoccus. For example, the major fatty acids iso- $\mathrm{C}_{15: 0}$ and anteiso$\mathrm{C}_{15: 0}$, the predominant menaquinone $\mathrm{MK}-7$ and the low DNA G $+\mathrm{C}$ content $(41.0-41.2 \mathrm{~mol} \%)$ were similar to those of members of the genus Jeotgalicoccus. By contrast, strains $\mathrm{C} 1-52^{\mathrm{T}}$ and YD-9 could be distinguished from members of the genus Salinicoccus, which possess MK-6 as the major menaquinone and have a higher DNA G+C content (46-51 mol\%; Ventosa et al., 1990, 1993).

It has been suggested that bacterial strains with $<97 \% 16 \mathrm{~S}$ rRNA gene sequence similarity should be classified in different genomic species (Stackebrandt \& Goebel, 1994). Therefore, the phylogenetic data in this study showed that strains $\mathrm{C} 1-52^{\mathrm{T}}$ and YD-9 were not related to J. pinnipedialis CCUG $42722^{\mathrm{T}}$, J. huakuii NY-2 ${ }^{\mathrm{T}}$ or J. marinus JSM $076033^{\mathrm{T}}$ at the species level. DNA-DNA hybridization was performed between the isolates and their closest phylogenetic neighbours, J. halotolerans JCM $11198^{\mathrm{T}}$ and J. psychrophilus JCM $11199^{\mathrm{T}}$. DNA was sheared by 


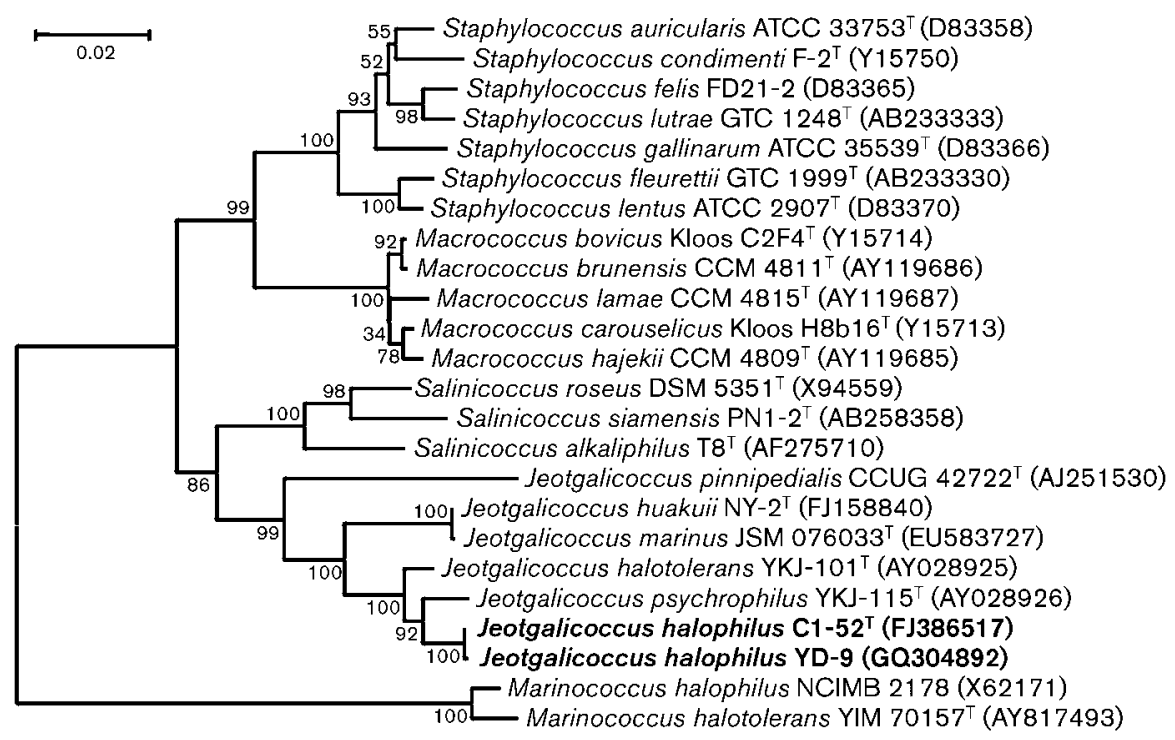

Fig. 1. Neighbour-joining phylogenetic tree based on 16S rRNA gene sequences showing the relationships between strains C1-52 ${ }^{\top}$ and YD-9 and type strains of species of the genus Jeotgalicoccus and species of other closely related genera. Bootstrap values $(>50 \%)$ based on 1000 replications are shown at branch nodes. Bar, 0.02 substitutions per site.

sonication (Braun Melsungen) at $50 \mathrm{~W}$ for three periods of $10 \mathrm{~s}$ and renaturation was performed in $2 \times \mathrm{SSC}$ at $69^{\circ} \mathrm{C}$. Levels of DNA-DNA relatedness were estimated spectrophotometrically (De Ley et al., 1970; Huß et al., 1983). Strains C1 $-52^{\mathrm{T}}$ and YD-9 shared, respectively, 20 and $11 \%$ DNA-DNA relatedness with $J$. halotolerans JCM $11198^{\mathrm{T}}$ and 8 and $13 \%$ with J. psychrophilus JCM $11199^{\mathrm{T}}$. DNADNA relatedness between strains $\mathrm{C} 1-52^{\mathrm{T}}$ and $\mathrm{YD}-9$ was $91 \%$. Because $<70 \%$ DNA-DNA relatedness is a key marker for the identification of a novel species (Wayne et al., 1987), it is clear that the isolates belong to the same species and represent a previously unknown species of the genus Jeotgalicoccus.

The phylogenetic and chemotaxonomic analyses suggested that strains $\mathrm{C} 1-52^{\mathrm{T}}$ and $\mathrm{YD}-9$ belong to the genus Jeotgalicoccus. Moreover, phenotypic features, DNA-DNA relatedness, DNA base composition and phylogenetic analysis clearly revealed that the isolates belong to a species that is different from J. halotolerans, J. psychrophilus, J. marinus, J. huakuii and J. pinnipedialis. In conclusion, it is proposed to place strains $\mathrm{C} 1-52^{\mathrm{T}}$ and YD-9 in a novel species of the genus Jeotgalicoccus, for which the name Jeotgalicoccus halophilus sp. nov. is proposed.

\section{Description of Jeotgalicoccus halophilus sp. nov.}

Jeotgalicoccus halophilus (ha.lo.phi'lus. Gr. n. hals halos salt; Gr. adj. philos loving; N.L. masc. adj. halophilus salt-loving).

The species description is based on two isolates. Cells are cocci $(0.5-0.8 \mu \mathrm{m})$, Gram-positive and non-motile. Colonies are circular, smooth, entire, slightly raised, pale yellow and 1-2 $\mathrm{mm}$ in diameter after 3 days. A light pink, diffusible pigment is produced after a few additional days of incubation. Grows with $0.1-16 \%(\mathrm{w} / \mathrm{v}) \mathrm{NaCl}$ (optimum $2-3 \% \mathrm{NaCl}$ ), at $4-40{ }^{\circ} \mathrm{C}$ (optimum $30-35{ }^{\circ} \mathrm{C}$ ) and at $\mathrm{pH}$ 5.5-10 (optimum $\mathrm{pH}$ 7.5). Catalase, oxidase, urease and phenylalanine deaminase are produced, but phosphatase, lecithinase and arginine dihydrolase are not. Produces acid from D-fructose, D-glucose, D-mannitol (type strain) and sucrose, but not from maltose, D-xylose, trehalose, lactose, arabinose or D-galactose. Hydrolyses starch, casein and tyrosine, but not aesculin, gelatin, xanthine, hypoxanthine or Tween 80 . As sole sources of carbon and energy, utilizes D-mannitol (type strain), sucrose, D-fructose, Dglucose and maltose, but not cellobiose, D-galactose, glycogen, lactose, D-mannose, L-arabinose, trehalose or Dxylose. Voges-Proskauer and methyl red tests are negative. Nitrate is not reduced to nitrite. $\mathrm{H}_{2} \mathrm{~S}$ and indole are not produced. Susceptible to $\left(\mu \mathrm{g} \mathrm{ml}^{-1}\right)$ rifampicin (5), ampicillin (30) and gentamicin (40), but not to streptomycin (100), chloramphenicol (20), kanamycin (100), erythromycin (50), tetracycline (20), spectinomycin (50) or nalidixic acid (30). The menaquinones and peptidoglycan type of the type strain are MK-7 and MK-6 and L-Lys-Gly ${ }_{3-4}-\mathrm{L}-$ $\mathrm{Ala}(\mathrm{Gly})$. The major cellular fatty acids ( $>5 \%$ of the total) are anteiso- $\mathrm{C}_{15: 0}$, iso- $\mathrm{C}_{15: 0}$ and iso- $\mathrm{C}_{17: 1} \omega 10 c$. The DNA $\mathrm{G}+\mathrm{C}$ content is $41.0-41.2 \mathrm{~mol} \%$.

The type strain is $\mathrm{C} 1-52^{\mathrm{T}}$ (=CGMCC $1.8911^{\mathrm{T}}=\mathrm{NBRC}$ $105788^{\mathrm{T}}$ ), isolated from Daban salt lake in Xinjiang, China. A strain has also been isolated from Aiding salt lake.

\section{Acknowledgements}

This work was supported financially by the Chinese International Science and Technology Cooperation (grant number 2006DFA31060). We are grateful to Y. Zhou (China General Microbiological Culture 
Collection Center, Institute of Microbiology, Chinese Academy of Sciences), W.-J. Li (The Key Laboratory for Microbial Resources of the Ministry of Education, PR China, and Laboratory for Conservation and Utilization of Bio-Resources, Yunnan Institute of Microbiology, Yunnan University) and J.-D. Jiang (Key Laboratory for Microbiological Engineering of the Agricultural Environment, Ministry of Agriculture, Nanjing Agricultural University) for providing biological samples.

\section{References}

Chen, Y.-G., Cui, X.-L., Pukall, R., Li, H.-M., Yang, Y.-L., Xu, L.-H., Wen, M.-L., Peng, Q. \& Jiang, C.-L. (2007). Salinicoccus kunmingensis sp. nov., a moderately halophilic bacterium isolated from a salt mine in Yunnan, south-west China. Int J Syst Evol Microbiol 57, 2327-2332.

Chen, Y.-G., Zhang, Y.-Q., Shi, J.-X., Xiao, H.-D., Tang, S.-K., Liu, Z.-X., Huang, K., Cui, X.-L. \& Li, W.-J. (2009). Jeotgalicoccus marinus sp. nov., a marine bacterium isolated from a sea urchin. Int J Syst Evol Microbiol 59, 1625-1629.

Collins, M. D. (1985). Isoprenoid quinone analysis in classification and identification. In Chemical Methods in Bacterial Systematics, pp. 267-287. Edited by M. Goodfellow \& D. E. Minnikin. London: Academic Press.

Cowan, S. T. \& Steel, K. J. (1965). Manual for the Identification of Medical Bacteria. London: Cambridge University Press.

De Ley, J., Cattoir, H. \& Reynaerts, A. (1970). The quantitative measurement of DNA hybridization from renaturation rates. Eur $J$ Biochem 12, 133-142.

Doetsch, R. N. (1981). Determinative methods of light microscopy. In Manual of Methods for General Bacteriology, pp. 21-33. Edited by P. Gerhardt, R. G. E. Murray, R. N. Costilow, E. W. Nester, W. A. Wood, N. R. Krieg \& G. H. Phillips. Washington, DC: American Society for Microbiology.

Dong, X.-Z. \& Cai, M.-Y. (editors) (2001). Determination of biochemical properties. In Manual for Systematic Identification of General Bacteria, pp. 370-398. Beijing: Science Press.

Duckworth, A. W., Grant, W. D., Jones, B. E. \& van Steenbergen, R. (1996). Phylogenetic diversity of soda lake alkaliphiles. FEMS Microbiol Ecol 19, 181-191.

Gregersen, T. (1978). Rapid method for distinction of Gram-negative from Gram-positive bacteria. Eur J Appl Microbiol Biotechnol 5, 123-127.

Guo, X.-O., Li, R., Zheng, L.-Q., Lin, D.-O., Sun, J.-O., Li, S.-P., Li, W.-J. \& Jiang, J.-D. (2010). Jeotgalicoccus huakuii sp. nov., a halotolerant bacterium isolated from seaside soil. Int J Syst Evol Microbiol 60, 1307-1310.

Hall, T. A. (1999). BioEdit: a user-friendly biological sequence alignment editor and analysis program for Windows 95/98/NT. Nucleic Acids Symp Ser 41, 95-98.

Hoyles, L., Collins, M. D., Foster, G., Falsen, E. \& Schumann, P. (2004). Jeotgalicoccus pinnipedialis sp. nov., from a southern elephant seal (Mirounga leonina). Int J Syst Evol Microbiol 54, 745-748.

Huß, V. A. R., Festl, H. \& Schleifer, K. H. (1983). Studies on the spectrophotometric determination of DNA hybridization from renaturation rates. Syst Appl Microbiol 4, 184-192.

Kimura, M. (1980). A simple method for estimating evolutionary rates of base substitutions through comparative studies of nucleotide sequences. J Mol Evol 16, 111-120.
Kumar, S., Tamura, K. \& Nei, M. (2004). MEGA3: integrated software for molecular evolutionary genetics analysis and sequence alignment. Brief Bioinform 5, 150-163.

Lányí, B. (1987). Classical and rapid identification methods for medically important bacteria. Methods Microbiol 19, 1-67.

Larsen, P. I., Sydnes, L. K., Landfald, B. \& Strøm, A. R. (1987). Osmoregulation in Escherichia coli by accumulation of organic osmolytes: betaines, glutamic acid, and trehalose. Arch Microbiol 147, 1-7.

Leifson, E. (1963). Determination of carbohydrate metabolism of marine bacteria. J Bacteriol 85, 1183-1184.

Marmur, J. (1961). A procedure for the isolation of deoxyribonucleic acid from micro-organisms. J Mol Biol 3, 208-218.

Marmur, J. \& Doty, P. (1962). Determination of the base composition of deoxyribonucleic acid from its thermal denaturation temperature. $J$ Mol Biol 5, 109-118.

Schleifer, K. H. (1985). Analysis of the chemical composition and primary structure of murein. Methods Microbiol 18, 123-156.

Schleifer, K. H. \& Kandler, O. (1972). Peptidoglycan types of bacterial cell walls and their taxonomic implications. Bacteriol Rev 36, 407-477.

Shirling, E. B. \& Gottlieb, D. (1966). Methods for characterization of Streptomyces species. Int J Syst Bacteriol 16, 313-340.

Smibert, R. M. \& Krieg, N. R. (1994). Phenotypic characterization. In Methods for General and Molecular Bacteriology, pp. 607-654. Edited by P. Gerhardt, R. G. E. Murray, W. A. Wood \& N. R. Krieg. Washington, DC: American Society for Microbiology.

Stackebrandt, E. \& Goebel, B. M. (1994). Taxonomic note: a place for DNA-DNA reassociation and $16 \mathrm{~S}$ rRNA sequence analysis in the present species definition in bacteriology. Int J Syst Bacteriol 44, 846-849.

Thompson, J. D., Gibson, T. J., Plewniak, F., Jeanmougin, F. \& Higgins, D. G. (1997). The CLUSTAL_X windows interface: flexible strategies for multiple sequence alignment aided by quality analysis tools. Nucleic Acids Res 25, 4876-4882.

Tindall, B. J., Rosselló-Móra, R., Busse, H.-J., Ludwig, W. \& Kämpfer, P. (2010). Notes on the characterization of prokaryote strains for taxonomic purposes. Int J Syst Evol Microbiol 60, 249-266.

Ventosa, A., Marquez, M. C., Ruiz-Berraquero, F. \& Kocur, M. (1990). Salinicoccus roseus gen. nov., sp. nov., a new moderately halophilic gram-positive coccus. Syst Appl Microbiol 13, 29-33.

Ventosa, A., Marquez, M. C., Kocur, M. \& Tindall, B. J. (1993). Comparative study of 'Micrococcus sp.' strains CCM 168 and CCM 1405 and members of the genus Salinicoccus. Int J Syst Bacteriol 43, 245-248.

Wayne, L. G., Brenner, D. J., Colwell, R. R., Grimont, P. A. D., Kandler, O., Krichevsky, M. I., Moore, L. H., Moore, W. E. C., Murray, R. G. E. \& other authors (1987). International Committee on Systematic Bacteriology. Report of the ad hoc committee on reconciliation of approaches to bacterial systematics. Int J Syst Bacteriol 37, 463-464.

Xu, D., Huang, J., Zhang, J., Fan, Q. \& Liu, D. (1995). A new species of genus Halomonas - Halomonas huanghaiensis sp. nov. Acta Microbiol Sin 35, 315-321 (in Chinese).

Yoon, J.-H., Lee, K.-C., Weiss, N., Kang, K. H. \& Park, Y.-H. (2003). Jeotgalicoccus halotolerans gen. nov., sp. nov. and Jeotgalicoccus psychrophilus sp. nov., isolated from the traditional Korean fermented seafood jeotgal. Int J Syst Evol Microbiol 53, 595-602. 